\title{
Lactobacillus casei Shirota administered during lactation increases the duration of autoimmunity in rats and enhances lung inflammation in mice
}

\author{
Janine Ezendam ${ }^{1} *$ and Henk van Loveren ${ }^{1,2}$ \\ ${ }^{1}$ National Institute for Public Health and the Environment (RIVM), Laboratory for Health Protection Research, Bilthoven, \\ The Netherlands \\ ${ }^{2}$ Nutrition and Toxicology Research Institute Maastricht (NUTRIM), Department of Health Risk Analysis and Toxicology (GRAT), \\ Maastricht University, Maastricht, The Netherlands
}

(Received 20 November 2006 - Revised 23 May 2007 - Accepted 29 May 2007)

Probiotics are considered to have beneficial effects on the immune system. An association between the composition of microflora and allergies has been demonstrated and modulation of microflora of infants by probiotics might reduce the risk of allergies. To investigate immune effects of probiotics administered early after birth two animal models were used: a mouse model for respiratory allergy; a rat model for experimental autoimmune encephalomyelitis (EAE). Administration of the probiotic Lactobacillus casei Shirota (LcS) started during lactation and allergy or autoimmunity were induced at an adult age. Results were compared with similar studies in rats and mice that were exposed from an adult age. Early administration of LcS significantly increased lymphocytes in the lungs of female mice and eosinophils in the lungs of male mice. LcS had no effects on ovalbumin-specific serum IgE levels and on ovalbumin-specific cytokine production by spleen cells. In adult mice, LcS enhanced ovalbumin-specific cytokine production by the spleen, whereas other parameters were not affected. Early administration of LcS to rats significantly increased the duration of clinical symptoms of EAE. This was also demonstrated previously in adult rats exposed to LcS. Timing of administration of $\mathrm{LcS}$ induced divergent effects on respiratory allergy and only early administration of LcS exacerbated lung inflammation. In the EAE model, LcS stimulated autoimmunity independent of the timing of administration. Our data show that immune effects of probiotics do not necessarily induce beneficial effects. It is therefore important that, in the evaluation of probiotics, efficacy and safety should be demonstrated.

Probiotics: Lactobacillus casei Shirota: Allergy: Autoimmunity: Lactation

At birth the gastrointestinal tract is sterile, but it becomes rapidly colonized by microbes. The microflora changes in the first weeks after birth and its composition is influenced by, among other things, the type of feeding ${ }^{1}$. Breast-fed infants are colonized predominantly with bifidobacteria and lactobacilli, whereas the microflora of formula-fed infants is composed of less bifidobacteria and lactobacilli and more anaerobic strains, such as bacteroides and clostridia ${ }^{2-4}$. When solid foods are introduced into the diet, each individual develops a unique and complex microflora ${ }^{5}$. It has been shown in several studies that the intestinal bacterial flora plays a crucial role in the generation of an appropriate functioning immune system ${ }^{6-8}$. Furthermore, an association between the composition of intestinal microflora and allergies has been observed in a study comparing microflora from allergic and non-allergic children. Allergic children were less often colonized with lactobacilli and bifidobacteria than non-allergic children ${ }^{9}$.

The association between composition of the microflora and allergies has brought up the idea that modulation of the microflora could beneficially influence the immune system ${ }^{10-12}$.
Supplementation of infant formulas with probiotics might alter the composition of the microflora of formula-fed infants in such a way that it resembles that of breast-fed infants. This may reduce the chance of developing an allergy. Evidence for beneficial effects of probiotics on allergy has been found in experimental animal models ${ }^{13-18}$. In human subjects, there are several studies that have shown improvement or prevention of atopic eczema in infants who received Lactobacillus rhamnosus strain GG (LGG) ${ }^{19-21}$. However, another study showed that neither L. rhamnosus nor LGG could improve atopic eczema ${ }^{22}$. In addition, L. acidophilus did not prevent the development of atopic eczema in atopic infants. Notably, in infants who received this probiotic the rate of sensitization was higher ${ }^{23}$. These studies show that the beneficial effects of probiotics on atopic manifestations are strain-dependent and that modulation of the immune system does not always lead to allergy prevention and can also increase allergic sensitization.

One of the mechanisms that could explain the beneficial effects of probiotics on allergies is the ability of some probiotic strains to stimulate T-helper (Th)-1 immunity, thereby

Abbreviations: CFU, colony forming units; EAE, experimental autoimmune encephalomyelitis; IFN, interferon; LcS, Lactobacillus casei Shirota; LGG, Lactobacillus rhamnosus strain GG; MBP, myelin basic protein; Th, T helper; TLR, toll-like receptor.

* Corresponding author: Janine Ezendam, fax +31 30 2744446, email Janine.Ezendam@rivm.nl 
reducing Th2 responses and thus (Th2-mediated) aller$\operatorname{gies}^{24-26}$. However, stimulation of Th1 immunity might aggravate Th1-mediated autoimmune diseases. We have previously demonstrated that $L$. casei Shirota $(\mathrm{LcS})$, indeed, aggravated experimental autoimmune encephalomyelitis (EAE) in Lewis rats ${ }^{27}$. Similar results were found for L. reuteri in a mouse model for $\mathrm{EAE}^{28}$. These experimental data suggest that certain probiotic strains can induce adverse effects.

Probiotics are considered to be safe due to their long-term use in the adult population without any adverse effects. The adverse effects on experimental autoimmunity, however, indicate that side effects could be possible. Infants might be more vulnerable to the adverse effects of probiotics, especially since the developing immune system is more susceptible to immunomodulation, as has been shown previously for dexamethasone. Neonatal treatment increased the severity and incidence of EAE in adult life ${ }^{29}$. This could imply that infants are a group at risk. Although the short-term safety of probiotics in infants has been investigated ${ }^{30}$, long-term effects have not yet been investigated.

In this paper we have investigated effects of LcS administered early in life (during lactation) on the development of respiratory allergy (in mice) or EAE (in rats), which was induced at the adult age. To compare the consequences of $\mathrm{LcS}$ administration early in life on allergy development at an adult age, similar experiments were performed in mice that received $\mathrm{LcS}$ as adults. Effects of LcS on EAE were compared with our previous study, in which rats were exposed to LcS as adults $^{27}$.

\section{Materials and methods}

\section{Bacteria}

LcS, isolated from a commercially available drink (Yakult ${ }^{\mathrm{TM}}$, Yakult Nederland BV, Almere, The Netherlands), was cultured for $72 \mathrm{~h}$ at $30^{\circ} \mathrm{C}$ under anaerobic conditions in Man Rogosa Sharpe broth (CM359; Oxoid, Haarlem, The Netherlands). Thereafter, bacteria were washed twice with saline $(0.9 \% \mathrm{NaCl})$ containing $1 \mathrm{mg} / \mathrm{ml}$ peptone (saline/peptone) and resuspended in saline/peptone to a final concentration of $2 \times 10^{9}$ colony forming units $(\mathrm{CFU}) / \mathrm{ml}$. The number and viability of the lactobacilli were determined by aerobic culturing on Man Rogosa Sharpe plates (CM361; Oxoid) for $72 \mathrm{~h}$.

\section{Animals}

Female and male BALB/c mice (6-8 weeks old) were obtained from our own breeding colony. For experiments where LcS administration started during lactation, 2-week old female and male BALB/c mice born to pregnant BALB/ c mice obtained from our own breeding colony were used. Mice were bred specific pathogen free and kept under conventional conditions. The breeding colony of the animals was prescreened/monitored for endogenous pathogenic viruses and bacteria and was found negative. For the autoimmunity experiments 2-week old female and male Lewis rats (LEW/ HanHsD) born to pregnant Lewis rats obtained from Harlan (Horst, The Netherlands) were used. Mice and rats were fed Hope Farms chow pellets (Woerden, The Netherlands) and water ad libitum. The experimental set-up of all experiments was examined and agreed upon by the institute's Ethical Committee on Experimental Animals, according to national legislation.

\section{Experimental design respiratory allergy}

To study the effects of LcS exposure early after birth, young suckling pups were used. After birth, the pups were randomized and cross-suckled between the dams. Each nest contained the same number of pups with an equal male:female ratio. LcS was given via oral gavage and administration started when the mice were 2 weeks old until the end of the experiment. Mice received $2-4 \times 10^{8} \mathrm{CFU} \mathrm{LcS}$ or saline/peptone alone (controls) daily in a volume of $100 \mu \mathrm{l}$, except for the first week when $2-4 \times 10^{8} \mathrm{CFU}$ was administered in $50 \mu \mathrm{l}$. At weaning (21 d after birth) mice were taken away from their mothers and housed in the experimental groups. Mice were sensitized and challenged with ovalbumin (eight females and eight males per experimental group) as described earlier ${ }^{31}$ with some minor modifications. Mice were sensitized twice, first when they were 6 weeks old (day 0) and for a second time on day 14 , by intraperitoneal injection with $10 \mathrm{mg}$ ovalbumin (grade V; Sigma-Aldrich, Zwijndrecht, The Netherlands) adsorbed onto $2.25 \mathrm{mg}$ aluminium hydroxide (AlumInject, Pierce, Rockford, IL, USA) in saline. Control mice (four females and four males per control group) were sensitized with saline. Mice were challenged on days 35,38 and 41 by inhalation of ovalbumin or saline aerosols in a plexiglass exposure chamber for $20 \mathrm{~min}$. Aerosols were generated by nebulizing a solution of $10 \mathrm{mg} / \mathrm{ml}$ ovalbumin in saline or saline alone using a nebulizer. At day 43, mice were killed and blood was collected, clotted and serum was collected for determination of ovalbumin specific Ig. Spleens were collected and cell suspensions were prepared for ex vivo stimulation with ovalbumin.

Adult (6-8 weeks old) female (eight for the experimental and four for the control group) and male (eight for the experimental and four for the control group) mice were used to compare effects of early administration of $\mathrm{LcS}$ on allergy. Oral gavage with LcS started 1 week before sensitization with ovalbumin. The sensitization and challenge protocol was the same as described earlier.

\section{Bronchoalveolar lavage}

Bronchoalveolar lavage was performed by flushing the lungs with $1 \mathrm{ml}$ sterile PBS. Bronchoalveolar lavage fluid was centrifuged at $1200 \mathrm{rpm}$ for $10 \mathrm{~min}$. Cell pellets were used for determination of total cell number and for cytospin preparations. Cytospins were stained with May-Grünwald (Fluka, Seelze, Germany) and Giemsa (Merck, Darmstadt, Germany) and on each preparation 400 cells were counted.

\section{Culture of spleen cells}

Spleens were collected and single-cell suspensions were prepared under aseptic conditions by pressing the spleen through a sterile $70 \mu \mathrm{m}$ nylon cell strainer. Cells were washed in RPMI 1640 (Gibco, Life Technologies, Breda, The Netherlands) with $5 \%$ heat inactivated fetal calf serum (PAA, Linz, Austria), $100 \mathrm{U} / \mathrm{ml}$ penicillin and $100 \mu \mathrm{g} / \mathrm{ml}$ streptomycin 
(standard medium) $\left(10 \mathrm{~min}, 4^{\circ} \mathrm{C}, 300 \mathrm{~g}\right)$ and resuspended in $1 \mathrm{ml}$ standard medium with $10 \%$ fetal calf serum. Cell suspensions $\left(2 \times 10^{6}\right.$ cells $/ \mathrm{ml}, 75 \mu \mathrm{l}$ per well $)$ were cultured for $96 \mathrm{~h}$ with $100 \mu \mathrm{g} / \mathrm{ml}$ ovalbumin $(75 \mu l$ per well). Supernatants were collected for cytokine measurements.

\section{ELISA specific for ovalbumin $\operatorname{IgE}$ and $\operatorname{Ig} G 1$}

Specific ovalbumin IgE and IgG1 titres in sera were determined by ELISA. Incubations were followed by extensive washing on an automatic plate washer with PBS containing $0.1 \%$ Tween-20. To measure ovalbumin-specific IgE, 96well plates (Nunc-Immuno Plate, Nunc A/S, Roskilde, Denmark) were coated overnight at $4^{\circ} \mathrm{C}$ with $2 \mu \mathrm{g} / \mathrm{ml}$ rat-antimouse IgE (r $\alpha \mathrm{m}$ IgE; Zymed Laboratories, San Francisco, CA, USA) diluted in sodium carbonate buffer ( $\mathrm{pH} 9.6)$ and incubated overnight at $4^{\circ} \mathrm{C}$. Plates were blocked by adding $0 \cdot 05 \mathrm{M}$-Tris buffered saline with $1 \%$ bovine serum albumin, $\mathrm{pH} 8$ (Sigma) for $1 \mathrm{~h}$ at $37^{\circ} \mathrm{C}$. Thereafter, serial dilutions of mouse serum samples and a pooled positive reference serum were incubated for $1 \mathrm{~h}$ at $37^{\circ} \mathrm{C}$. All dilutions were done in blocking buffer plus $0.05 \%$ Tween-20. Then, wells were incubated for $1 \mathrm{~h}$ at $37^{\circ} \mathrm{C}$ with digoxigenin-3-O-succinyl- $\varepsilon$-aminocaproic acid (DIG)-conjugated ovalbumin. The coupling of ovalbumin to DIG (molar mixture 1:10) was performed according to the manufacturer's instructions (Roche Diagnostics $\mathrm{GmbH}$, Mannheim, Germany). Then, wells were incubated with anti-DIG Fab fragments labelled with peroxidase (Roche Diagnostics) for $2 \mathrm{~h}$ at $37^{\circ} \mathrm{C}$. Plates were incubated with tetramethyl benzidine (TMB) substrate and the enzyme reaction was stopped with $2 \mathrm{M}-\mathrm{H}_{2} \mathrm{SO}_{4}$ and absorbance was read at $450 \mathrm{~nm}$.

To measure ovalbumin-specific IgG1, wells were coated overnight at $4^{\circ} \mathrm{C}$ with $10 \mu \mathrm{g} / \mathrm{ml}$ ovalbumin/ml PBS (grade $\mathrm{V}$; Sigma). Blocking buffer was added and wells were incubated for $1 \mathrm{~h}$ at $37^{\circ} \mathrm{C}$. Thereafter, serial dilutions of mouse serum samples and a pooled positive reference serum were added to the wells and incubated for $2 \mathrm{~h}$ at room temperature (RT). Biotinylated rat-anti-mouse IgG1 (Zymed Laboratories) was added and wells were incubated for $1.5 \mathrm{~h}$ at RT, followed by incubation with poly-horseradish peroxidase labelled streptavidin for $45 \mathrm{~min}$ at RT. Then plates were incubated with TMB substrate and the enzyme reaction was stopped with $2 \mathrm{M}-\mathrm{H}_{2} \mathrm{SO}_{4}$ and absorbance was read at $450 \mathrm{~nm}$. Extinction values of the positive reference serum were used to calculate the amount of $\operatorname{IgG} 1$ and $\operatorname{IgE}$ in the samples and extinction values were expressed as arbitrary units.

\section{Bioplex for cytokines}

Th1 and Th2 cytokines were measured in supernatants of spleen cells that were cultured with ovalbumin. Cytokine levels were detected with a Bioplex 5-plex cytokine assay kit that contained antibodies specific for IL-4, IL-5, IL-10, IL-13 and interferon (IFN)- $\gamma$ (Biorad Life Science, Hercules, CA, USA) according to the manufacturer's instructions. Cytokine measurements were performed on a Luminex ${ }^{\circledR}($ Biorad Life Science) and Luminex software was used to calculate the amount of cytokines ( $\mathrm{pg} / \mathrm{ml}$ supernatant). The range of detection for each cytokine was: for IL-4 $0 \cdot 18-424 \mathrm{pg} / \mathrm{ml}$; for IL-5 $1.3-1051 \mathrm{pg} / \mathrm{ml}$; for IL-10 $14.6-3556 \mathrm{pg} / \mathrm{ml}$; for IFN- $\gamma$ : $0 \cdot 52-3566 \mathrm{pg} / \mathrm{ml}$; for IL-13: $4 \cdot 3-30782 \mathrm{pg} / \mathrm{ml}$.

\section{Experimental design for experimental autoimmune encephalomyelitis}

After birth, the pups were randomized and cross-suckled between the dams. Each nest contained the same amount of pups with an equal male:female ratio. Oral administration of LcS started when the rats were 2 weeks old. Rats received $1-2 \times 10^{9} \mathrm{CFU}$ daily in a volume of $500 \mu \mathrm{l}$. Control rats received $500 \mu \mathrm{l}$ saline/peptone daily. At weaning ( $21 \mathrm{~d}$ old), rats were taken away from their mothers and housed in the experimental groups.

Acute EAE was induced at the age of 7 weeks as described previously $^{32}$. Rats (eight females and eight males per experimental group) were injected subcutaneously in the left ankle. Males were dosed with an emulsion $(100 \mu l)$ containing $20 \mu \mathrm{g}$ guinea pig myelin basic protein (MBP; Sigma), $500 \mu \mathrm{g}$ Mycobacterium tuberculosis type H37RA (Difco, Detroit, MI, USA), $50 \mu \mathrm{l}$ complete Freund's adjuvant (Difco) supplemented with saline $(0.9 \% \mathrm{NaCl})$ to reach a volume of $100 \mu \mathrm{l}$. Females were dosed with the same solution $(80 \mu \mathrm{l})$. The dose for immunization with MBP is dependent on body weight and females were lighter than males at the age of 7 weeks. Control rats (four females and four females per control group) were not immunized and received either $\mathrm{LcS}$ or saline/peptone. After induction of EAE, body weight was recorded daily. Also, neurological signs were scored daily and graded from 1 to 5: 0 , no clinical signs; 0.5 , loss of tonicity in distal half of tail; 1 , flaccid tail; $1 \cdot 5$, unsteady gait; 2 , partial hind limb paralysis; $2 \cdot 5$, complete hind limb paralysis; 3 , paralysis of the complete lower part of the body up to the diaphragm; 4, paraplegia; 5, death due to EAE. Rats were killed $27 \mathrm{~d}$ after induction of EAE. The clinical score is expressed as the cumulative clinical score per rat and was calculated by cumulating the daily clinical scores. In addition, duration of EAE was defined by the number of days that rats display clinical signs of EAE per animal. The cumulative disease index was defined as the sum of the cumulative daily scores per group divided by the amount of days that clinical disease signs were observed in the group.

\section{Power calculations}

The number of animals per experimental group was calculated with a power analysis using data from previous experiments. ExpDesign software, a freely available tutorial program, was used for power analysis ${ }^{33}$. The $P$ value was set at $<0.05$ and the number of animals per group was considered to be sufficient when the power was $>0 \cdot 8$.

\section{Statistical analysis}

In both the allergy and the EAE experiments, both sexes were included in the experiments, because at initiation LcS administration was performed in litter. Previously, it has been demonstrated that females are more susceptible for the sensitization with ovalbumin ${ }^{34}$ and immunization with $\mathrm{MBP}^{35,36}$. In addition, the immunization with MBP was based on body weight and since females were lighter than males they were 
immunized with less MBP, because overdosing can be lethal. The statistical analysis was therefore done in males and females separately.

Statistical analysis was performed with SPSS software (SPSS Inc., Chicago, IL, USA). Data are presented as means with their standard errors. The $P$ value for statistical significant differences was set at $<0 \cdot 05$. When data were not normally distributed they were ${ }^{10} \log$ transformed prior to analysis.

To determine statistically significant differences in cell number in lung lavage fluid, a one-way ANOVA was used. The Levene test was used for homogeneity of variance. When the variance was not equal, the Games-Howell test was used as a post hoc test, otherwise Bonferroni's post hoc test was used. Statistical significant differences in ovalbumin-specific cytokine production and ovalbumin-specific $\mathrm{IgE}$ and IgG1 levels were determined with a two-tailed Student's $t$ test comparing the two experimental groups that were sensitized and challenged with ovalbumin. Statistical difference of clinical symptoms and duration of symptoms in the EAE experiment between the experimental groups that were immunized with EAE were determined with a one-tailed Mann-Whitney test.

\section{Results}

\section{Respiratory allergy}

Bronchoalveolar lavage: cell counts and differentiation. Table 1 shows the cell counts in lung lavage fluid when LcS administration started during lactation. Ovalbumin sensitized and challenged female and male mice showed significantly increased numbers of total cells compared with controls. This increase was predominantly due to an increase in eosinophils and lymphocytes. Influx of eosinophils and lymphocytes after challenge with ovalbumin was more pronounced in female mice than in male mice. In sensitized female mice that received $\mathrm{LcS}$, total cell number and eosinophils were higher, but these differences were not significantly different from sensitized mice that received the vehicle. The observed increase in lymphocytes, however, was significantly different from the sensizited group $(P=0.026)$. In males, total cell number was slightly higher in sensitized mice that received $\mathrm{LcS}$, but this was not significant. The number of lymphocytes was not different between both sensitized groups. A significant increase in eosinophils was observed in sensitized mice that received $\operatorname{LcS}(P=0 \cdot 018)$.

Table 2 shows the cell counts in lung lavage fluid when $\mathrm{LcS}$ was administered to adult mice. In sensitized females, total cell number, macrophages, eosinophils and lymphocytes were significantly higher than the control group. Administration of LcS did not affect cell number in sensitized mice. The total cell number in control males was higher than male controls in the other experiment (Table 1) and in the controls that received LcS. A significant increase in eosinophils was found in both sensitized groups compared with the control group. Total cell number was significantly higher when compared with the controls that received LcS $(P=0.020$ and $P=0.018$ for sensitized males that received vehicle or $\mathrm{LcS}$, respectively). Also in males, LcS had no effects on the inflammatory lung response.

\section{Ovalbumin-specific cytokine production}

To assess if cytokine profiles were affected by LcS administration, spleen cells were cultured with ovalbumin to detect specific cytokine production. In mice that received LcS from lactation onward, no differences in specific cytokine production could be detected (data not shown). In adult mice that received LcS, however, cytokine production was enhanced (Table 3). In females, all Th2 cytokines were increased in the LcS group. For IL-5 and IL-13 this was significant, for IL-4 $(P=0.089)$ and IL10 $(P=0.063)$ this was not. IFN- $\gamma$ levels were comparable in both groups. In males,

Table 1. Number of cells in lung lavage fluid in mice that received Lactobacillus casei Shirota (LcS) from lactation onward§

(Mean values with their standard errors)

\begin{tabular}{|c|c|c|c|c|c|c|c|c|c|}
\hline \multirow[b]{2}{*}{ Group } & \multirow[b]{2}{*}{$n$} & \multicolumn{2}{|c|}{ Totalł } & \multicolumn{2}{|c|}{ Macrophages } & \multicolumn{2}{|c|}{ Eosinophils } & \multicolumn{2}{|c|}{ Lymphocytes } \\
\hline & & Mean & SE & Mean & SE & Mean & SE & Mean & SE \\
\hline \multicolumn{10}{|l|}{ Females } \\
\hline Control & 4 & 0.16 & 0.02 & 0.15 & 0.02 & ND & & ND & \\
\hline Control + LcS & 4 & $0 \cdot 13$ & 0.01 & 0.11 & 0.01 & ND & & ND & \\
\hline OVA & 8 & $0.65^{\star \star}$ & 0.12 & 0.24 & 0.04 & $0.36^{*}$ & 0.09 & $0.09^{\star \star \star}$ & 0.02 \\
\hline OVA + LcS & 8 & $1 \cdot 01^{\star \star}$ & 0.27 & 0.21 & 0.03 & 0.58 & $0 \cdot 18$ & $0 \cdot 28^{*} \dagger$ & 0.08 \\
\hline \multicolumn{10}{|l|}{ Males } \\
\hline Control & 4 & 0.13 & 0.01 & 0.13 & 0.01 & ND & & 0.003 & \\
\hline Control + LcS & 4 & 0.14 & 0.02 & 0.14 & 0.02 & ND & & 0.005 & \\
\hline OVA & 8 & $0 \cdot 28^{\star \star}$ & 0.04 & 0.22 & 0.04 & $0 \cdot 013^{\star \star \star}$ & 0.004 & $0.046^{\star \star}$ & 0.025 \\
\hline OVA + LcS & 8 & $0.39^{\star \star \star}$ & 0.02 & 0.28 & 0.02 & $0.058^{\star \star \star} \dagger$ & 0.016 & $0.051^{\star \star *}$ & 0.011 \\
\hline
\end{tabular}

Mean values were significantly different from those of the control group: ${ }^{\star} P<0.05 ;{ }^{* \star} P<0.01 ;{ }^{* \star *} P<0.001$. Data were log transformed before statistical analysis. To determine statistical significance a one-way ANOVA with Bonferroni's post hoc test or Games-Howell (when variance was not equal in the Levene's test) post hoc test was used.

Mean values were significantly different from those of the ovalbumin (OVA) group: $† P<0.05$.

$\ddagger$ Cell numbers are expressed in $10^{6}$ cells.

$\S$ For details of animals and procedures, see Materials and methods.

ND, not detected. 
Table 2. Number of cells in lung lavage fluid in mice that received Lactobacillus casei Shirota (LcS) at adult agef (Mean values with their standard errors)

\begin{tabular}{|c|c|c|c|c|c|c|c|c|c|}
\hline \multirow[b]{2}{*}{ Group } & \multirow[b]{2}{*}{$n$} & \multicolumn{2}{|c|}{ Total† } & \multicolumn{2}{|c|}{ Macrophages } & \multicolumn{2}{|c|}{ Eosinophils } & \multicolumn{2}{|c|}{ Lymphocytes } \\
\hline & & Mean & SE & Mean & SE & Mean & SE & Mean & SE \\
\hline \multicolumn{10}{|l|}{ Females } \\
\hline Control & 4 & 0.15 & 0.002 & 0.14 & 0.003 & ND & & 0.002 & 0.001 \\
\hline Control + LcS & 4 & 0.24 & 0.02 & $0 \cdot 17$ & 0.02 & ND & & 0.023 & 0.008 \\
\hline OVA & 8 & $1 \cdot 14^{\star \star \star}$ & 0.18 & $0.31^{\star *}$ & 0.04 & $0.41^{* *}$ & 0.08 & $0 \cdot 27^{\star \star \star}$ & 0.06 \\
\hline OVA + LcS & 8 & $0.94^{\star \star \star}$ & 0.09 & $0 \cdot 29^{\star}$ & 0.04 & $0 \cdot 26^{\star \star}$ & 0.06 & $0 \cdot 27^{\star \star \star}$ & 0.04 \\
\hline \multicolumn{10}{|l|}{ Males } \\
\hline Control & 4 & 0.26 & 0.09 & 0.25 & 0.08 & ND & & 0.019 & 0.01 \\
\hline Control + LcS & 4 & 0.13 & 0.02 & 0.13 & 0.02 & ND & & 0.006 & 0.002 \\
\hline OVA & 8 & 0.34 & 0.04 & 0.28 & 0.04 & 0.019 & 0.008 & 0.024 & 0.006 \\
\hline OVA + LcS & 8 & 0.35 & 0.04 & 0.27 & 0.08 & 0.032 & 0.012 & 0.042 & 0.008 \\
\hline
\end{tabular}

Mean values are significantly different from the control group: ${ }^{\star} P<0.05 ;{ }^{\star \star} P<0.01 ;{ }^{\star \star \star} P<0.001$. Data were log transformed before statistical analysis. To determine statistical significance a one-way ANOVA with Bonferroni's post hoc test or Games-Howell (when variance was not equal in the Levene's test) post hoc test was used.

† Cell numbers are expressed in $10^{6}$ cells

$\ddagger$ For details of animals and procedures, see Materials and methods.

OVA, ovalbumin; ND, not detected.

all Th2 cytokines were significantly higher in the LcS group. IFN- $\gamma$ was also higher in this group but this was not significant $(P=0 \cdot 09)$.

\section{Ovalbumin-specific IgG1 and IgE levels}

Both ovalbumin-specific IgG1 and IgE titres were detectable after sensitization and challenge with ovalbumin. IgE titres were significantly higher in females than in males, IgG1 titres were similar. Administration of LcS either during lactation or when mice were adults did not affect IgG1 or IgE titres significantly (data not shown).

\section{Experimental autoimmune encephalomyelitis}

After immunization with MBP, the first clinical symptom that was observed was loss of tonicity in the tail. In males, there was no difference on the day of onset of EAE for vehicle-treated rats (between days 14 and 18) and LcS-treated rats (between days 15 and 21) after immunization. In Table 4 several clinical parameters are summarized. In vehicle-treated rats, six out of eight animals developed clinical symptoms, whereas all LcS-treated rats developed EAE. Other parameters, such as clinical score per rat, duration of symptoms and cumulative disease index, were not affected by LcS. In females, day of onset was similar in vehicle-treated rats (between days 12 and 18) and LcS-treated rats (between days 11 and 18). Table 4 shows that all females that received $\mathrm{LcS}$ developed clinical symptoms, while six of the eight rats that received vehicle developed EAE. Furthermore, after LcS administration, clinical score per animal and cumulative disease index were higher. The effect on clinical score was not significant however. In addition, LcS significantly increased the duration of symptoms, the disease symptoms lasted almost $3 \mathrm{~d}$ longer $(P=0 \cdot 026)$.

\section{Discussion}

We have investigated the effects of administration of the probiotic LcS, starting during lactation, on the development of

Table 3. Ovalbumin-specific cytokine production by spleen cells from mice that received Lactobacillus casei Shirota (LCS) at adult agef

(Mean values with their standard errors)

\begin{tabular}{|c|c|c|c|c|c|c|c|c|c|c|c|}
\hline \multirow[b]{2}{*}{ Group } & \multirow[b]{2}{*}{$n$} & \multicolumn{2}{|c|}{ IL-4† } & \multicolumn{2}{|c|}{ IL-5 } & \multicolumn{2}{|c|}{ IL-10 } & \multicolumn{2}{|c|}{ IL-13 } & \multicolumn{2}{|c|}{ IFN- $\gamma$} \\
\hline & & Mean & SE & Mean & SE & Mean & SE & Mean & SE & Mean & SE \\
\hline \multicolumn{12}{|l|}{ Females } \\
\hline OVA & 8 & 12 & 2.5 & 181 & 68 & 32 & 8.9 & 102 & 42 & 11 & $5 \cdot 4$ \\
\hline OVA + LcS & 8 & 19 & $3 \cdot 1$ & $429^{*}$ & 81 & 72 & 18 & $345^{\star}$ & 90 & 14 & $3 \cdot 2$ \\
\hline \multicolumn{12}{|l|}{ Males } \\
\hline OVA & 8 & 0.52 & 0.08 & $1 \cdot 3$ & & $14 \cdot 6$ & & 4.3 & & 21 & 9.5 \\
\hline OVA + LcS & 8 & $21^{\star \star}$ & $3 \cdot 8$ & $187^{\star *}$ & 44 & $46^{*}$ & 10 & $165^{\star}$ & 48 & 62 & 21 \\
\hline
\end{tabular}

Mean values are significantly different from the ovalbumin (OVA) group: ${ }^{\star} P<0.05 ;{ }^{\star \star} P<0.01$ (to determine statistical significance a two-tailed Student's $t$ test was used).

†Cytokines are expressed as $\mathrm{pg} / \mathrm{ml}$ supernatant

$\ddagger$ For details of animals and procedures, see Materials and methods.

IFN, interferon. 
Table 4. Summary of clinical parameters of experimental autoimmune encephalomyelitis (EAE) $)^{\star \star}$ (Mean values with their standard errors)

\begin{tabular}{|c|c|c|c|c|c|c|c|c|}
\hline \multirow[b]{2}{*}{ Group } & \multicolumn{2}{|c|}{ Day of onset† } & \multirow[b]{2}{*}{ Incidence $\ddagger$} & \multicolumn{2}{|c|}{ Clinical score§ } & \multicolumn{2}{|c|}{$\begin{array}{l}\text { Duration of } \\
\text { symptoms\| }\end{array}$} & \multirow[b]{2}{*}{ CDII } \\
\hline & Mean & SE & & Mean & SE & Mean & SE & \\
\hline \multicolumn{9}{|l|}{ Females } \\
\hline EAE/vehicle & $15 \cdot 7$ & 0.8 & $6 / 8$ & $2 \cdot 9$ & 1.5 & $3 \cdot 4$ & 1.4 & $1 \cdot 6$ \\
\hline $\mathrm{EAE} / \mathrm{LcS}$ & $15 \cdot 3$ & 0.9 & $8 / 8$ & $4 \cdot 2$ & 1.8 & $6 \cdot 6^{\star}$ & 1.0 & $2 \cdot 2$ \\
\hline \multicolumn{9}{|l|}{ Males } \\
\hline EAE/vehicle & $15 \cdot 7$ & 0.6 & $6 / 8$ & $4 \cdot 6$ & 2.9 & $4 \cdot 6$ & 1.2 & $2 \cdot 6$ \\
\hline EAE/LcS & $17 \cdot 5$ & 0.8 & $8 / 8$ & 4.0 & 1.2 & $5 \cdot 0$ & 1.0 & $2 \cdot 6$ \\
\hline
\end{tabular}

Mean values were significantly different from those of the EAE/vehicle group: ${ }^{*} P<0.05$.

†The first day a rat displayed clinical symptoms for all rats with symptoms.

$\ddagger$ The number of rats with clinical symptoms.

$\S$ The cumulative clinical scores per rat at the end of the experiment.

\| The number of days an animal displayed symptoms.

ๆ The sum of the daily clinical scores for a group over a given number of days divided by the number of days, given as a cumulative

disease index (CDI).

** For details of animals and procedures, see Materials and methods.

LcS, Lactobacillus casei Shirota.

allergy and autoimmunity at an adult age. Early administration of $\mathrm{LcS}$ stimulated both allergic and autoimmune responses. Although effects were moderate, these data confirm that LcS has immunostimulatory properties.

When LcS was given during lactation, the inflammatory lung response was enhanced in males and females. Remarkably, when LcS administration started when mice were adults, there was no effect on the influx of inflammatory cells. The stimulatory effects of $\mathrm{LcS}$ were confined to the lungs, because no effect of ovalbumin-specific IgE was observed. This is in contrast with previous studies that demonstrated a reduction of serum IgE by $\mathrm{LcS}^{18,37}$. This discrepancy might be explained by the different models that were used and the different route of exposure. In a model for food allergy in transgenic (OVA-TCR) mice, LcS was injected intraperitoneally ${ }^{18}$, while in the present study LcS was given via the oral route. However, in mice that were sensitized to ovalbumin by intraperitoneal injection oral administration of $\mathrm{LcS}$ decreased ovalbumin-specific IgE levels ${ }^{37}$. The observed effects on IgE were attributed to a shift in Th1/Th2 balance of cytokine production towards Th1. We could only detect effects on cytokine production in adult mice that received $\mathrm{LcS}$ and $\mathrm{LcS}$ did not induce a shift of the immune balance towards Th1, but stimulated predominantly Th2 cytokines and, to a lesser extent, Th1. The ability of probiotics to stimulate both Th1 and Th2 cytokines was previously shown for L. rhamnosus HNO01 in a model for respiratory allergy ${ }^{38}$.

Early administration of $\mathrm{LcS}$, however, did not elicit different or more pronounced effects in the EAE model compared with adult administration. Previously, we have shown that $\mathrm{LcS}$ aggravated $\mathrm{EAE}^{27}$. When $\mathrm{LcS}$ was given during lactation, an increase of incidence and duration of clinical symptoms in females was observed. In contrast, in males LcS increased the incidence of EAE, but did not affect clinical symptoms. It is important to note that the increase in incidence is an observational one, which is not tested statistically because the study was not powered to perform statistical analysis. These observations are in line with our previous study ${ }^{27}$. Our data suggest that $\mathrm{LcS}$ in general adjuvates both Th1 and Th2 responses, rather than skewing the immune system towards Th1. Stimulation of the immune response by LcS has been shown previously in a host resistance model for Listeria monocytogenesis $^{39,40}$

The effects of probiotics on the immune system are clearly strain-dependent ${ }^{28,41,42}$, but the mechanisms behind this are not completely understood. One way in which the immune system could recognize probiotics is via toll-like receptors (TLR). These receptors are present on immune cells and play an important role in the recognition and initiation of immune responses against pathogenic microorganisms ${ }^{43}$. There is some evidence from studies in experimental animals that TLR are involved in the immune effects elicited by probiotics. In an animal model for colitis, TLR9 mediated the anti-inflammatory effects induced by a mix of eight probiotic bacteria (VSL\#3) ${ }^{44}$. TLR9 was also involved in the suppression of allergic airway inflammation in a mouse model by $L$. reuteri ${ }^{41}$. Amelioration of experimental colitis by E. coli Nissle 1917 was dependent on TLR-2- and TLR-4-signalling ${ }^{45}$. TLR are present on dendritic cells, which are the principal stimulators of naïve $T$ cells. As such, they play a crucial role in polarization of the immune response to Th1, Th2 or regulatory $\mathrm{T}$ cell responses $^{46}$. In vitro studies have shown that probiotics can activate dendritic cells and influence $\mathrm{T}$ cell polarization towards $\mathrm{Th} 1$ or regulatory $\mathrm{T}$ cells ${ }^{47-49}$. Hence, dendritic cells seem to be involved in orchestrating the immune response induced by probiotics.

In our opinion, the proper probiotic strain should be selected in order to reach the goal for which the specific application is meant. This is illustrated by a recent study, in which it was shown that probiotics increase allergic sensitization in atopic infants who received L. acidophilus in the first 6 months of their life ${ }^{23}$. Probiotics are considered to be safe because of long-term use in the adult population, but information of safety in infants is scarce. The follow-up of most intervention studies in infants is relatively short to get insight into long-term beneficial and adverse effects. In atopic infants who received LGG in the first 6 months after birth, a followup until the age of 4 years was reported and, although the 
incidence of atopic dermatitis was significantly lower in the LGG group, the incidence of rhinitis was diagnosed twice as often. This finding was not significant due to the small number of infants with rhinitis ${ }^{19}$.

In conclusion, modulation of the immune system does not necessarily lead to beneficial effects. Therefore, more research is needed to elucidate the complexity of the mechanisms underlying these immune effects. For a better understanding of effects of intervention with probiotics early in life, wellcontrolled studies in infants are needed that focus on both short-term and long-term beneficial and adverse effects.

\section{Acknowledgements}

We acknowledge the Food and Consumer Product Safety Authority (VWA) for financial support. For excellent technical assistance we thank Arja de Klerk, Eric Gremmer, Bert Verlaan, Bianca Matthee, Liset de la Fonteyne and Yvonne Wallbrink from the Laboratory for Toxicology, Pathology and Genetics of the RIVM. We thank Hans Strootman, Dirk Elberts, Piet van Schaaik, Christine Soputan and Jouke van de Siepkamp from PMP department of the experimental animal laboratory of the Dutch Vaccine Institute (NVI) for the biotechnical support.

\section{References}

1. Fanaro S, Chierici R, Guerrini P \& Vigi V (2003) Intestinal microflora in early infancy: composition and development. Acta Paediatr 91, Suppl., 48-55.

2. Harmsen HJ, Wildeboer-Veloo AC, Raangs GC, Wagendorp AA, Klijn N, Bindels JG \& Welling GW (2000) Analysis of intestinal flora development in breast-fed and formula-fed infants by using molecular identification and detection methods. J Pediatr Gastroenterol Nutr 30, 61-67.

3. Kalliomaki M, Kirjavainen P, Eerola E, Kero P, Salminen S \& Isolauri E (2001) Distinct patterns of neonatal gut microflora in infants in whom atopy was and was not developing. J Allergy Clin Immunol 107, 129-134.

4. Penders J, Thijs C, Vink C, Stelma FF, Snijders B, Kummeling I, van den Brandt PA \& Stobberingh EE (2006) Factors influencing the composition of the intestinal microbiota in early infancy. Pediatrics 118, 511-521.

5. Edwards CA \& Parrett AM (2002) Intestinal flora during the first months of life: new perspectives. Br J Nutr 88, Suppl. 1, S11-S18.

6. Sudo N, Sawamura S, Tanaka K, Aiba Y, Kubo C \& Koga Y (1997) The requirement of intestinal bacterial flora for the development of an IgE production system fully susceptible to oral tolerance induction. J Immunol 159, 1739-1745.

7. Sudo N, Yu XN, Aiba Y, Oyama N, Sonoda J, Koga Y \& Kubo C (2002) An oral introduction of intestinal bacteria prevents the development of a long-term Th2-skewed immunological memory induced by neonatal antibiotic treatment in mice. Clin Exp Allergy 32, 1112-1116.

8. Macpherson AJ \& Harris NL (2004) Interactions between commensal intestinal bacteria and the immune system. Nat Rev Immunol 4, 478-485.

9. Bjorksten B, Naaber P, Sepp E \& Mikelsaar M (1999) The intestinal microflora in allergic Estonian and Swedish 2-yearold children. Clin Exp Allergy 29, 342-346.

10. Perdigon G, Locascio M, Medici M, Pesce de Ruiz Holgado A \& Oliver G (2003) Interaction of bifidobacteria with the gut and their influence in the immune function. Biocell 27, 1-9.
11. Meydani SN \& Ha WK (2000) Immunologic effects of yogurt. Am J Clin Nutr 71, 861-872.

12. Isolauri E, Sutas $\mathrm{Y}$, Kankaanpaa $\mathrm{P}$, Arvilommi H \& Salminen $\mathrm{S}$ (2001) Probiotics: effects on immunity. Am J Clin Nutr 73, Suppl. 2, 444S-450S.

13. Murosaki S, Yamamoto Y, Ito K, Inokuchi T, Kusaka H, Ikeda H \& Yoshikai Y (1998) Heat-killed Lactobacillus plantarum L-137 suppresses naturally fed antigen-specific IgE production by stimulation of IL-12 production in mice. J Allergy Clin Immunol 102, 57-64.

14. Kim H, Kwack K, Kim D-Y \& Ji GE (2005) Oral probiotic bacterial administration suppressed allergic responses in an ovalbumin-induced allergy mouse model. FEMS Immunology and Medical Microbiology 45, 259-267.

15. Matsuzaki T, Yamazaki R, Hashimoto S \& Yokokura T (1998) The effect of oral feeding of Lactobacillus casei strain Shirota on immunoglobulin E production in mice. J Dairy Sci 81, 48-53.

16. Kim H, Lee S-Y \& Ji G (2005) Timing of Bifidobacterium administration influences the development of allergy to ovalbumin in mice. Biotechnology Letters 27, 1361-1367.

17. Shida K, Makino K, Morishita A, et al. (1998) Lactobacillus casei inhibits antigen-induced $\operatorname{IgE}$ secretion through regulation of cytokine production in murine splenocyte cultures. Int Arch Allergy Immunol 115, 278-287.

18. Shida K, Takahashi R, Iwadate E, Takamizawa K, Yasui H, Sato T, Habu S, Hachimura S \& Kaminogawa S (2002) Lactobacillus casei strain Shirota suppresses serum immunoglobulin E and immunoglobulin G1 responses and systemic anaphylaxis in a food allergy model. Clin Exp Allergy 32, $563-570$

19. Kalliomaki M, Salminen S, Poussa T, Arvilommi H \& Isolauri E (2003) Probiotics and prevention of atopic disease: 4-year follow-up of a randomised placebo-controlled trial. Lancet 361, 1869-1871.

20. Kalliomaki M, Salminen S, Arvilommi H, Kero P, Koskinen P \& Isolauri E (2001) Probiotics in primary prevention of atopic disease: a randomised placebo-controlled trial. Lancet 357, 1076-1079.

21. Rosenfeldt V, Benfeldt E, Nielsen SD, Michaelsen KF, Jeppesen DL, Valerius NH \& Paerregaard A (2003) Effect of probiotic Lactobacillus strains in children with atopic dermatitis. J Allergy Clin Immunol 111, 389-395.

22. Brouwer ML, Wolt-Plompen SA, Dubois AE, van der Heide S, Jansen DF, Hoijer MA, Kauffman HF \& Duiverman EJ (2006) No effects of probiotics on atopic dermatitis in infancy: a randomized placebo-controlled trial. Clin Exp Allergy 36, 899-906.

23. Taylor AL, Dunstan JA \& Prescott SL (2007) Probiotic supplementation for the first 6 months of life fails to reduce the risk of atopic dermatitis and increases the risk of allergen sensitization in high-risk children: a randomized controlled trial. J Allergy Clin Immunol 119, 184-191.

24. Matsuzaki T (1998) Immunomodulation by treatment with Lactobacillus casei strain Shirota. Int J Food Microbiol 41, 133-140.

25. Kato I, Tanaka K \& Yokokura T (1999) Lactic acid bacterium potently induces the production of interleukin-12 and interferongamma by mouse splenocytes. Int J Immunopharmacol 21, 121-131.

26. Pohjavuori E, Viljanen M, Korpela R, Kuitunen M, Tiittanen M, Vaarala O \& Savilahti E (2004) Lactobacillus GG effect in increasing IFN-gamma production in infants with cow's milk allergy. J Allergy Clin Immunol 114, 131-136.

27. Baken KA, Ezendam J, Gremmer ER, de Klerk A, Pennings JL, Matthee B, Peijnenburg AA \& van Loveren H (2006) Evaluation of immunomodulation by Lactobacillus casei Shirota: immune function, autoimmunity and gene expression. Int $J$ Food Microbiol 112, 8-18. 
28. Maassen $\mathrm{CB}$, van Holten JC, Balk F, Heijne den BakGlashouwer MJ, Leer R, Laman JD, Boersma WJ \& Claassen E (1998) Orally administered Lactobacillus strains differentially affect the direction and efficacy of the immune response. Vet $Q$ 20, Suppl. 3, S81-S83.

29. Bakker JM, Kavelaars A, Kamphuis PJ, Cobelens PM, van Vugt HH, van Bel F \& Heijnen CJ (2000) Neonatal dexamethasone treatment increases susceptibility to experimental autoimmune disease in adult rats. J Immunol 165, 5932-5937.

30. Kullen MJ \& Bettler J (2005) The delivery of probiotics and prebiotics to infants. Curr Pharm Des 11, 55-74.

31. Smit JJ, van Loveren H, Hoekstra MO, Nijkamp FP \& Bloksma $N$ (2003) Influence of the macrophage bacterial resistance gene, Nramp1 (Slc11a1), on the induction of allergic asthma in the mouse. Faseb J 17, 958-960.

32. Hendriks JJ, Alblas J, van der Pol SM, van Tol EA, Dijkstra CD \& de Vries HE (2004) Flavonoids influence monocytic GTPase activity and are protective in experimental allergic encephalitis. J Exp Med 200, 1667-1672.

33. van Wilgenburg $\mathrm{H}$, van Schaick Zillesen PG \& Krulichova I (2003) Sample Power and ExpDesign: tools for improving design of animal experiments. Lab Anim (NY) 32, 39-43.

34. Melgert BN, Postma DS, Kuipers I, Geerlings M, Luinge MA, van der Strate BW, Kerstjens HA, Timens W \& Hylkema MN (2005) Female mice are more susceptible to the development of allergic airway inflammation than male mice. Clin Exp Allergy 35, 1496-1503.

35. Bebo BF, Schuster JC, Vandenbark AA \& Offner H (1998) Gender differences in experimental autoimmune encephalomyelitis develop during the induction of the immune response to encephalitogenic peptides. J Neurosci Res 52, 420-426.

36. Bebo BF Jr, Schuster JC, Vandenbark AA \& Offner H (1999) Androgens alter the cytokine profile and reduce encephalitogenicity of myelin-reactive T cells. J Immunol 162, 35-40.

37. Yasui H, Shida K, Matsuzaki T \& Yokokura T (1999) Immunomodulatory function of lactic acid bacteria. Antonie Van Leeuwenhoek 76, 383-389.

38. Cross ML, Mortensen RR, Kudsk J \& Gill HS (2002) Dietary intake of Lactobacillus rhamnosus HNOO1 enhances production of both Th1 and Th2 cytokines in antigen-primed mice. Med Microbiol Immunol (Berl) 191, 49-53.

39. de Waard R, Claassen E, Bokken GC, Buiting B, Garssen J \& Vos JG (2003) Enhanced immunological memory responses to
Listeria monocytogenes in rodents, as measured by delayedtype hypersensitivity (DTH), adoptive transfer of DTH, and protective immunity, following Lactobacillus casei Shirota ingestion. Clin Diagn Lab Immunol 10, 59-65.

40. de Waard R, Garssen J, Bokken GC \& Vos JG (2002) Antagonistic activity of Lactobacillus casei strain shirota against gastrointestinal Listeria monocytogenes infection in rats. Int $J$ Food Microbiol 73, 93-100.

41. Forsythe P, Inman MD \& Bienenstock J (2007) Oral treatment with live Lactobacillus reuteri inhibits the allergic airway response in mice. Am J Respir Crit Care Med 175, $561-569$

42. Maassen CB, van Holten-Neelen C, Balk F, den Bak-Glashouwer MJ, Leer RJ, Laman JD, Boersma WJ \& Claassen E (2000) Strain-dependent induction of cytokine profiles in the gut by orally administered Lactobacillus strains. Vaccine $\mathbf{1 8}$, 2613-2623.

43. Takeda K \& Akira S (2005) Toll-like receptors in innate immunity. Int Immunol 17, 1-14.

44. Rachmilewitz D, Katakura K, Karmeli F, et al. (2004) Toll-like receptor 9 signaling mediates the anti-inflammatory effects of probiotics in murine experimental colitis. Gastroenterology 126, 520-528.

45. Grabig A, Paclik D, Guzy C, et al. (2006) Escherichia coli strain Nissle 1917 ameliorates experimental colitis via toll-like receptor 2- and toll-like receptor 4-dependent pathways. Infect Immun 74, 4075-4082.

46. Kapsenberg ML (2003) Dendritic-cell control of pathogendriven T-cell polarization. Nat Rev Immunol 3, 984-993.

47. Christensen HR, Frokiaer H \& Pestka JJ (2002) Lactobacilli differentially modulate expression of cytokines and maturation surface markers in murine dendritic cells. J Immunol 168, $171-178$

48. Mohamadzadeh M, Olson S, Kalina WV, Ruthel G, Demmin GL, Warfield KL, Bavari S \& Klaenhammer TR (2005) Lactobacilli activate human dendritic cells that skew T cells toward T helper 1 polarization. Proc Natl Acad Sci U S A 102, $2880-2885$.

49. Smits HH, Engering A, van der Kleij D, et al. (2005) Selective probiotic bacteria induce IL-10-producing regulatory $\mathrm{T}$ cells in vitro by modulating dendritic cell function through dendritic cell-specific intercellular adhesion molecule 3-grabbing nonintegrin. J Allergy Clin Immunol 115, 1260-1267. 